\title{
JEKK
}

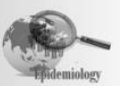

\section{Diabetic Status of People Affected by Leprosy in Donorojo Leprosy Recovered Village: A Cross Sectional Study}

\author{
Nadhila Beladina*, Asri Adisasmita ${ }^{* *}$ \\ *Postgraduate Program of Epidemiology Departement, Public Health Universitas Indonesia, Depok \\ ** Epidemiology Departement, Faculty of Public Health Universitas Indonesia, Depok
}

\begin{abstract}
Background: Just like diabetes, leprosy also cause painless neuropathic ulcers which process is mediated by Schwann-cell. Biochemical changes on leprosy patients presumed to have role on pathogenesis of diabetes mellitus.

Methods: This study is cross-sectional study aimed to know further about diabetic status on population of people affected by leprosy, as the preliminary study to prove the association between diabetes mellitus and leprosy. Data, such as diabetic status, type of leprosy, grade of disability, and other variables are collected from 127 people affected by leprosy in Donorojo leprosy recovered village.

Result: Result showed that $19.7 \%$ are having diabetes mellitus, and other $23.6 \%$ are in pre-diabetic condition. This number is higher than prevalence of diabetes mellitus in Central Java (2.09\%) and Indonesia (2\%).
\end{abstract}

Conclusion : Further research is needed to prove the association between leprosy and diabetic status. All leprosy patients should be recommended to be routinely screened for diabetes mellitus.

Keywords: Leprosy ; diabetes ; impaired glucose tolerance ; people affected by leprosy.

*Corresponding author, nadhilab@gmail.com 


\section{Introduction}

Non-communicable diseases have been a health challenge, not only to high-income countries, but also the low-income countries. ${ }^{1}$ $71 \%$ of global deaths in 2016 are caused by non-communicable disease, and $3 \%$ of them are caused by diabetes. Global diabetes cases were increased for almost 4 folds, from 108 million cases on 1980 to 422 million cases in 2014. ${ }^{2}$

In Indonesia, prevalence of diabetes was increasing, from $1,5 \%$ in 2013 to $2 \%$ in $2018 .^{3}$ Indonesia was the $7^{\text {th }}$ country in the world with highest number of diabetes cases among people aged 20-79 years old, reaching 10.7 million cases of diabetes. ${ }^{4}$

Diabetes is a chronic disease that occurs when pancreas can't produce enough amount of insulin, or when the body can't effectively use insulin that has been produced. ${ }^{3}$ Diabetes can cause damage to several organs, such as heart, blood vessels, eyes, kidney, nerves, and also cause complication, such as vision loss, stroke, heart attack, renal failure, even foot problems that lead to amputation if left untreated. ${ }^{2}$ Due to rapid increase of cases number and the complications it causes, diabetic is now become a priority in many countries.

Just like diabetes, leprosy can also cause loss of sensation on the limbs, especially foot, increasing the risk of getting wound unconsciously. ${ }^{5}$ Both diabetes and leprosy are known of causing neuropathic ulcers which process is mediated by Schwann cell. ${ }^{6}$ Biochemical changes on leprosy patients presumed to have role on pathogenesis of diabetes mellitus. $^{7}$

In 1979, survey of 120 people affected by leprosy in Jhansi, India showed that diabetes prevalence among people affected by leprosy $(14.2 \%)$ is 7 -folds higher than diabetes prevalence among normal population $(2 \%){ }^{8} \mathrm{~A}$ cross-sectional study in Bangladesh showed that 4\% among 3573 leprosy patients with disability are having diabetes. ${ }^{9}$ Case-control study in Kuwait in 2011 was also showing that diabetes incidence among cases group (people affected by leprosy) is higher than diabetes incidence among control group, with number of diabetes incidence reaching $13.3 \%$, and
$37.7 \%$ among the cases group are in prediabetic condition. ${ }^{7}$

Until 2018, Indonesia is still on $3^{\text {rd }}$ position, country with highest number of leprosy prevalence in the world, with number of 17.017 cases. ${ }^{10}$ With the similar complications caused by diabetes and leprosy, people affected by leprosy with diabetes are having higher risk to encounter vision loss or neuropathic ulcers.

Leprosy that mostly occurs among people with low-economic condition and strongly associated with stigma in society, causing lack of social support and resources for people affected by leprosy with diabetes to have further treatment.

This study is aimed to know further about diabetic status on population of people affected by leprosy in Donorojo leprosy recovered village, as the preliminary study to prove the association between diabetes mellitus and leprosy.

\section{Methods}

\section{Study Design}

This study is a cross-sectional study, carried out in 2019, in Donorojo leprosy recovered village Located in Jepara District, Central Java, Indonesia, to know number of diabetes prevalence among people affected by leprosy.

\section{Population and Sample}

Study population in this research is all people affected by leprosy that have finished their multi-drug therapy (MDT) treatment, that are living in Donorojo leprosy recovered village. Total sampling was used, so all study population who agreed to participate are all included in this research.

There were total 138 people affected by leprosy that live in Donorojo leprosy recovered village and have finished MDT treatment. Amongst them, 3 persons were refused to have their capillary blood taken and 8 were out of village when data were collected, so only 127 people affected by leprosy are included in this study as sample.

\section{Data Collection}

Data collection were carried out under permission of Donorojo Leprosy Hospital, the leprosy center hospital in Central Java. 
Variables for which data were collected including history of leprosy (type of leprosy, duration of disease, duration of treatment, and leprosy reaction experience), disability grade, random blood sugar level, and other variables such as age, gender, and family history of diabetes. Data collected only from participants that agreed to informed consent paper.

Data of diabetic status were collected through interview and measuring the blood sugar level. Participants that ever been diagnosed with diabetes by a doctor before will be grouped to subject with diabetes, although they showed normal level of blood sugar lever when measured. Blood sugar lever was measured by portable glucometer, and results will be classified based on World Health Organization's criteria, in which subjects with random blood sugar level are greater than or equal to $11.1 \mathrm{mmol} / \mathrm{L} \quad(200 \mathrm{mg} / \mathrm{dL})$ were addressed as diabetic. ${ }^{11}$ Consensus of Diabetes Management and Prevention applied in Indonesia is also stating that people with capillary random blood sugar level over or equal as $200 \mathrm{mg} / \mathrm{dL}$ are addressed as diabetic. ${ }^{12}$ As for people with capillary random blood sugar level in between 140-200 mg are classified as people with impaired glucose tolerance, or in pre-diabetic condition. Prediabetic subjects have a high risk of diabetes years in near future. ${ }^{11}$ Data about history of diabetes drugs consumption, change on lifestyle (diet, losing weight program, physical activities) was also collected from participants that ever been diagnosed with diabetes before.

Data about history of affected by leprosy (type of leprosy, duration of disease, duration of treatment, and leprosy reaction experience), age, gender, and family history of diabetes were collected by interview and observation. Duration of disease is duration from the appearance of sign and symptom of leprosy until they got treated using MDT (months). Duration of treatment defined as duration of leprosy treatment using MDT measured in months. Type of leprosy was classified according WHO definition, to paucibacillary (PB), and multibacillary (MB).

\section{Result}

127 from 138 people affected by leprosy that have finished the treatment and stated as release from treatment (RFT) in Donorojo leprosy recovered village were interviewed as participants. Participants consisted of 72 men $(56.7 \%)$ and 55 women (43.3\%), aged between 23-81 years old with average 52 years old. From 127 participants, 62 have paucibacillary type $(48.8 \%)$, and 65 have multibacillary type $(51.2 \%)$.

78 participants are $(61.4 \%)$ having grade 2 disabilities, based on WHO defined as visible deformity or damage presented. 18 participants $(14.2 \%)$ are having grade 1 disabilities, in which anaesthesia present, but no visible deformity or damage, and the rest 31 participants $(24.4 \%)$ are having grade 0 disabilities. Duration of disease, defined as duration from the appearance of sign and symptom of leprosy until they got treated using MDT, varied in range of $1-120$ months with

average of 37 months. As for duration of treatment, defined as duration of leprosy treatment using MDT, varied in range of 6-96 months, with average of 25 months.

Collected data are showing that 13 out of 127 participants in this study have high random blood sugar level exceeding $200 \mathrm{mg} / \mathrm{dL}$, thereof classified as subjects with diabetes. 10 participants that are having normal random blood sugar level when they were tested, and other 2 participants in pre-diabetic condition are also classified as subjects with diabetes, since they previously diagnosed with diabetes by doctor. Thus, in this study, we have total 25 participants $(19.7 \%)$ classified as subjects with diabetes. 
Table 1. Random blood sugar level of participants that previously have been diagnosed with diabetes

\begin{tabular}{|c|c|c|c|c|}
\hline $\begin{array}{l}\text { Characteris } \\
\text { tics }\end{array}$ & $\begin{array}{c}<140 \\
\mathrm{mg} / \mathrm{dL} \\
(\mathrm{norm} \\
\text { al) }\end{array}$ & $\begin{array}{c}\geq 140- \\
199 \\
\text { mg/dL } \\
\text { (pre- } \\
\text { diabet } \\
\text { es) } \\
\text { n }(\%)\end{array}$ & $\begin{array}{c}\geq 200 \\
\mathrm{mg} / \mathrm{dL} \\
\text { (diabet } \\
\text { es) }\end{array}$ & $\begin{array}{c}\text { Tota } \\
1 \\
(n=2 \\
5)\end{array}$ \\
\hline \multicolumn{5}{|l|}{ Gender } \\
\hline Male & 8 & - & 8 & 16 \\
\hline Female & 2 & 2 & 5 & 9 \\
\hline
\end{tabular}

30 from 127 participants $(23.6 \%)$ were having random blood sugar level in range of $140 \mathrm{mg} / \mathrm{dL}-199 \mathrm{mg} / \mathrm{dL}$, therefore classified as subjects with pre-diabetic condition. All diabetic cases happen to people affected by leprosy aged $\geq 45$ years old, as for pre-diabetic condition are more commonly found in people affected by leprosy aged $<45$ years old $(35.7 \%)$ than those who aged $\geq 45$ years old $(20.2 \%)$.

Prevalence of diabetes is higher in men $(22.2 \%)$ than in women $(16.4 \%)$, so does with prevalence of pre-diabetic condition that is higher in men $(27.8 \%)$ compared to prevalence of pre-diabetic condition in women $(18.2 \%)$.

Prevalence of diabetes is found higher in group of participants whose duration of disease is greater than or equal to 2 years and finished their treatment in 2 years or more. Prevalence of diabetes and prediabetic condition is also commonly found in participants who previously has experienced leprosy reaction, compared to participants who never been experiencing leprosy reaction.

Table 2. Comparison of diabetic status in people affected by leprosy based on their characteristic

\begin{tabular}{|c|c|c|c|c|}
\hline Characteristics & $\begin{array}{c}\text { Total } \\
(\mathbf{n}=\mathbf{1 2 7})\end{array}$ & $\begin{array}{l}\text { Normal n (\%) } \\
(95 \% \text { CI })\end{array}$ & $\begin{array}{c}\text { Diabetic Status } \\
\text { Pre-Diabetes n }(\%) \\
(95 \% \text { CI })\end{array}$ & $\begin{array}{c}\text { Diabetes n (\%) } \\
(95 \% \mathrm{CI})\end{array}$ \\
\hline \multicolumn{5}{|l|}{ Gender } \\
\hline Male & 72 & $\begin{array}{c}36(50.0) \\
(41.3-58.7)\end{array}$ & $\begin{array}{c}20(27.8) \\
(19.9-35.6)\end{array}$ & $\begin{array}{c}16(22.2) \\
(14.9-29.5)\end{array}$ \\
\hline Female & 55 & $\begin{array}{c}36(65.4) \\
(57.2-73.7)\end{array}$ & $\begin{array}{c}10(18.2) \\
(11.5-24.9)\end{array}$ & $\begin{array}{c}9(16.4) \\
(9.9-22.8)\end{array}$ \\
\hline \multicolumn{5}{|l|}{ Age } \\
\hline$<45$ years old & 28 & $\begin{array}{c}18(64.3) \\
(55.9-72.6)\end{array}$ & $\begin{array}{c}10(35.7) \\
(27.4-44.0)\end{array}$ & $\begin{array}{c}0(0.0) \\
-\end{array}$ \\
\hline$\geq 45$ years old & 99 & $\begin{array}{c}54(54.5) \\
(45.9-63.2)\end{array}$ & $\begin{array}{c}20(20.2) \\
(13.2-27.2)\end{array}$ & $\begin{array}{c}25(25.3) \\
(17.7-32.8)\end{array}$ \\
\hline \multicolumn{5}{|l|}{ Type of Leprosy } \\
\hline Paucibacillary & 62 & $\begin{array}{c}39(62.9) \\
(54.5-71.3)\end{array}$ & $\begin{array}{l}10(16.1) \\
(9.7-22.5)\end{array}$ & $\begin{array}{c}13(21.0) \\
(13.9-28.0)\end{array}$ \\
\hline Multibacillary & 65 & $\begin{array}{c}33(50.8) \\
(42.1-59.5)\end{array}$ & $\begin{array}{c}20(30.8) \\
(22.7-38.8)\end{array}$ & $\begin{array}{c}12(18.4) \\
(11.7-25.2)\end{array}$ \\
\hline \multicolumn{5}{|l|}{ Disability level } \\
\hline Grade 0 & 31 & $\begin{array}{c}16(51.6) \\
(42.9-60.3)\end{array}$ & $\begin{array}{c}13(41.9) \\
(33.3-50.5)\end{array}$ & $\begin{array}{c}2(6.5) \\
(2.2-10.7)\end{array}$ \\
\hline Grade 1 & 18 & $\begin{array}{c}11(61.1) \\
(52.6-69.6)\end{array}$ & $\begin{array}{c}5(27.8) \\
(19.9-35.6)\end{array}$ & $\begin{array}{c}2(11.1) \\
(5.7-16.6)\end{array}$ \\
\hline Grade 2 & 78 & $\begin{array}{c}45(57.7) \\
(49.1-66.3)\end{array}$ & $\begin{array}{l}12(15.4) \\
(9.1-21.7)\end{array}$ & $\begin{array}{c}21(26.9) \\
(19.2-34.6)\end{array}$ \\
\hline \multicolumn{5}{|l|}{ Duration of disease } \\
\hline$<2$ years & 47 & $\begin{array}{c}23(48.9) \\
(40.2-57.6)\end{array}$ & $\begin{array}{c}16(34.1) \\
(25.8-42.3)\end{array}$ & $\begin{array}{c}8(17.0) \\
(10.5-23.6)\end{array}$ \\
\hline$\geq 2$ years & 80 & $\begin{array}{c}49(61.3) \\
(52.8-69.7)\end{array}$ & $\begin{array}{c}14(17.5) \\
(10.9-24.1)\end{array}$ & $\begin{array}{c}17(21.2) \\
(14.1-28.4)\end{array}$ \\
\hline
\end{tabular}




\begin{tabular}{|c|c|c|c|c|}
\hline Characteristics & $\begin{array}{c}\text { Total } \\
(\mathbf{n}=127)\end{array}$ & $\begin{array}{c}\text { Normal n }(\%) \\
(95 \% \text { CI })\end{array}$ & $\begin{array}{c}\text { Diabetic Status } \\
\text { Pre-Diabetes n }(\%) \\
(95 \% \text { CI })\end{array}$ & $\begin{array}{c}\text { Diabetes n (\%) } \\
(95 \% \mathrm{CI})\end{array}$ \\
\hline \multicolumn{5}{|l|}{ Duration of treatment } \\
\hline$<2$ years & 50 & $\begin{array}{c}27(54.0) \\
(45.3-62.7)\end{array}$ & $\begin{array}{c}15(30.0) \\
(22.0-37.9)\end{array}$ & $\begin{array}{c}8(16.0) \\
(9.6-22.4)\end{array}$ \\
\hline$\geq 2$ years & 77 & $\begin{array}{c}45(58.4) \\
(49.9-67.0)\end{array}$ & $\begin{array}{c}15(19.5) \\
(12.6-26.4)\end{array}$ & $\begin{array}{c}17(22.1) \\
(14.9-29.3)\end{array}$ \\
\hline \multicolumn{5}{|c|}{ History of Leprosy Reaction } \\
\hline Never & 88 & $\begin{array}{c}54(61.4) \\
(52.9-69.8)\end{array}$ & $\begin{array}{c}18(20.4) \\
(13.4-27.5)\end{array}$ & $\begin{array}{c}16(18.2) \\
(11.5-24.9)\end{array}$ \\
\hline At least once & 39 & $\begin{array}{c}18(46.1) \\
(37.5-54.8)\end{array}$ & $\begin{array}{c}12(30.8) \\
(22.7-38.8)\end{array}$ & $\begin{array}{c}9(23.1) \\
(15.8-30.4)\end{array}$ \\
\hline
\end{tabular}

\section{Discussion}

Treatment of leprosy is known to cause several effects, one of which is diabetes, induced by steroid consumption. Generally, blood sugar level will increase 3 months since leprosy treatment using steroid is started. A study of 830 leprosy patients treated with steroid showed their high level of postprandial blood sugar level, varied between $230 \mathrm{mg} / \mathrm{dL}$ to $700 \mathrm{mg} / \mathrm{dL} .^{13}$

Several studies of people affected by leprosy, that have already finished their leprosy treatment are also showing higher prevalence of diabetes among people affected by leprosy compared to the general population. Study in Jhansi, Bihar, and Jharkhand, rural areas in India, showed that prevalence of diabetes in population of people affected by leprosy varied in range of $14.2 \%-16.06 \%$, so much higher than prevalence of diabetes in general population (2\%). Study conducted in Kuwait is also showing that frequency of diabetes among leprosy patients is higher than control group $(13.3 \%$ compared to $0 \%) .8,14$

The high prevalence number of diabetes among people affected by leprosy can be attributed to some factors, one of which is the increasing level of stress hormones epinephrine, glucagon, and cortisone on people affected by leprosy that is wellknown to raise blood sugar level. Moreover, it is noted that people affected by leprosy tend to have higher pro- inflammatory cytokine TNF- $\alpha$ level than people on population of control group. TNF- $\alpha$ produce reactive nitrogen intermediate as protective agent against Mycobacteria and intracellular organism. On the other side, pro-inflammatory cytokine TNF- $\alpha$ plays specific role in regulation of insulin receptor signalling. Increasing pro-inflammatory cytokines TNF- $\alpha$ is-known to be associated with insulin resistance in several conditions, such as obesity, aging, and after muscle damage. ${ }^{7,8}$

This study is also showed that prevalence of diabetes among population of people affected by leprosy in Donorojo leprosy recovered village pada is higher (19.7\%) than general population in District of Jepara $(3.13 \%)$, general population in Central Java Province $(2.09 \%)$, and Indonesia (2\%) in 2018. ${ }^{15,16}$ All diabetes cases in this study are happened on people affected by leprosy aged more than or equal to 45 years old.

Furthermore, this study found that 30 out of 127 participants are having impaired glucose tolerance or in pre-diabetic condition, with random blood sugar level in range of $140 \mathrm{mg} / \mathrm{dL}$ to $199 \mathrm{mg} / \mathrm{dL}$.

Prevalence of pre-diabetic condition tends to increase along with the aging of population. Aging process inducing the decrease of insulin sensitivity and alteration of pancreatic beta cell function resulting in insulin resistance. ${ }^{17}$ People aged more than 45 years old having the 
highest risk to have impaired glucose tolerance. $^{12}$

In opposite with that, the result of this study showed that prevalence of prediabetic condition is more commonly found among people affected by leprosy aged less than 45 years old (35.7\%), than among them who aged 45 years old or more $(20.2 \%)$.

Increasing number of diabetes incidences is more likely to be happened among people with multibacillary type of leprosy. Research by Nigam et al (1979) and Saraya et al (2012) showed that impaired glucose tolerance incidences are found higher among people with multibacillary leprosy compared to the incidences among people with paucibacillary leprosy group and the control group. ${ }^{7,8}$

In this study, prevalence number of diabetes in both group of people with multibacillary leprosy and paucibacillary leprosy are almost the same, but prevalence number of impaired glucose tolerance is found higher among people with multibacillary leprosy $(30.8 \%)$ than the prevalence of impaired glucose tolerance among people with paucibacillary leprosy $(16.1 \%)$. The high number of impaired glucose tolerance among people with multibacillary leprosy may be attributed to some factors such as infection severity, duration of infection and stress, which mainly catabolic in multibacillary leprosy, that is also an important cause of the development of impaired glucose tolerance. ${ }^{18}$

Furthermore, duration of leprosy disease and duration of the treatment could also be the factors inducing diabetes to people affected by leprosy. Research of 43 leprosy cases found that person whose duration of disease is at range of $0-6$ months tends to have normal glucose tolerance. Impaired glucose tolerance were found on person with duration of disease between 7-12 months, and the number grew high on group of people whose duration of disease are more than 2 years. ${ }^{19}$

Duration of leprosy treatment and leprosy reaction are also play a role on the development of impaired glucose tolerance. Multi drug therapy used in leprosy, and drugs used to treat leprosy reaction give effect on blood sugar level. Leprosy reaction is treated using systemic gluco-corticosteroid, that may cause steroid-induced diabetes mellitus, or worsen glycaemic condition of people affected by leprosy. ${ }^{20}$ Rifampicin, is one of drugs on multi drug therapy regimen that induce hepatic microsomal enzyme system, developing early phase of hyperglycaemia attributed to the augmented intestinal absorption. ${ }^{7,21}$

This study found that diabetes is more likely to happen in person who has duration of disease and duration disease and duration of leprosy treatment more than 2 years. Impaired glucose tolerance is more common to be happened among people whose duration of disease and duration of treatment less than 2 years. More people who previously experienced leprosy reaction is having diabetes and impaired glucose tolerance compared to people who never experienced leprosy reaction before.

In this study, participants are classified as people with diabetes if their random blood sugar level is found to be beyond $200 \mathrm{mg} / \mathrm{dL}$, or previously diagnosed with diabetes by a doctor. Out of 25 persons classified as diabetic, data collected from this study showed 10 persons were having normal random blood sugar level and 2 others indicated impaired glucose level. Normal blood sugar level on people with diabetes may be attributed to several factors, such as insulin therapy, diabetic drugs or herbal medicines consumption, specific diet, or routine physical activities. Proportion of participants who were receiving insulin therapy, consuming diabetic drugs or herbal medicines, doing specific diet and routine physical activity 
after diagnosed with diabetes can be seen

on Table 3.

Table 3. Factors attributed to blood sugar level among people previously diagnosed with diabetes $(n=25)$

\begin{tabular}{lcccccc}
\hline $\begin{array}{c}\text { Random blood sugar } \\
\text { level when data is } \\
\text { collected }\end{array}$ & $\begin{array}{c}\text { Total } \\
\text { Subjec } \\
\text { ts }\end{array}$ & $\begin{array}{c}\text { Received } \\
\text { insulin } \\
\text { therapy (\%) }\end{array}$ & $\begin{array}{c}\text { Consume } \\
\text { diabetic } \\
\text { drugs (\%) }\end{array}$ & $\begin{array}{c}\text { Consume } \\
\text { herbal } \\
\text { medicines } \\
(\%)\end{array}$ & $\begin{array}{c}\text { Specific } \\
\text { diet (\%) }\end{array}$ & $\begin{array}{c}\text { Routine } \\
\text { physical } \\
\text { activities (\%) }\end{array}$ \\
\hline$<140 \mathrm{mg} / \mathrm{dL}$ & 10 & 0 & $3(30.0)$ & $6(60.0)$ & $7(70.0)$ & $2(20.0)$ \\
$\geq 140-199 \mathrm{mg} / \mathrm{dL}$ & 2 & 0 & 0 & 0 & $2(100.0)$ & 0 \\
$\geq 200 \mathrm{mg} / \mathrm{dL}$ & 13 & $2(15.4)$ & $5(38.5)$ & $3(23.1)$ & $9(69.2)$ & $1(7.7)$ \\
\hline
\end{tabular}

This study also showed that diabetes is more likely to be happened to people with grade 2 diabetes. Prevalence number of diabetes among people with grade 2 disabilities $(26.9 \%)$ is much higher than prevalence of diabetes among people with grade 1 disabilities $(11.1 \%)$ and grade 0 diabetes $(6.5 \%)$.

Diabetes, that is more likely to be happened among people with grade 2 diabetes should be get special attention, notably related to prevention of wound, complication, and disability. Both leprosy and diabetes causing loss of sensation, mostly on feet, increasing risk of getting wound and ulceration. Furthermore, people affected by leprosy with diabetes are having higher risk to undergo tropic ulceration, neuro-osteoarthropathy, and vision loss. Moreover, low socioeconomic status, stigma and discrimination towards leprosy, and lack of social support that are often happen to people affected by leprosy could delay the wounds treatment to prevent further disabilities.

Limitation of this study lies on small number of participants. Using total sampling, we could only recruit 127 persons affected by leprosy as participants on this study, resulting on wide range of $95 \%$ CI. Statistically difference in proportions of people with pre-diabetes condition can only be found on some variables, such as age group, type of leprosy, and duration of disease. As for Proportion of people with diabetes is proven to be statistically different in groups with different grades of disabilities, in which number of diabetes cases is found to be higher in group of grade 2 disabilities, compared to grade 1 and 0 .

This study may be affected by recall bias, since data about history of affected by leprosy (type of leprosy, duration of disease, duration of treatment, and leprosy reaction experience), that happened in the past was collected using interview method. Thus, information regarding variable of exposure (history of leprosy) could not accurately describe conditions in population of people affected by leprosy.

\section{Conclusion}

Result of this study showed higher prevalence number of diabetes among population of people affected by leprosy. Diabetes is more likely to be happened to people with grade 2 disabilities. Diabetes on population of people affected by leprosy may cause further complication such as neuropathic ulcers, vision loss, and hindering the wounds treatment. Further research is needed to prove the association between leprosy and diabetes. Screening for diabetes is better to be routinely done in population of people affected by leprosy, to prevent further complication and disabilities.

\section{Acknowledgement}

Author is grateful to Donorojo Leprosy Hospital that has given the permission, and people affected by leprosy in Donorojo Leprosy Recovered Village who were well-cooperated to have their data collected for this study. 


\section{References}

1. Kassa M, Grace J. 2019. The Global Burden and Perspectives on Noncommunicable Diseases (NCDs) and the Prevention, Data Availability and Systems Approach of NCDs in Low-resource Countries. In: Non-communicable Diseases and Urbanization - A Global Perspective [Working Title] [Internet]. IntechOpen; p. 13. Available from: https://www.intechopen.com/books/ advanced-biometrictechnologies/liveness-detection-inbiometrics

2. WHO. 2018. Noncommunicable Diseases. 1st ed. Geneva: WHO.

3. Kementerian Kesehatan Republik Indonesia. 2019. Infodatin Hari Diabetes Sedunia Tahun 2018. 1st ed. Pusat Data dan Informasi Kementrian Kesehatan RI. Jakarta: Kementerian Kesehatan Republik Indonesia; 1-8 p.

4. IDF. 2019. IDF Diabetes Atlas 2015 [Internet]. 9th ed. International Diabetes Federation. Brussels: International Diabetes Federation. 39 Available from: http://www.idf.org/aboutdiabetes/facts-figures

5. Boulton AJM. 2012. Diabetic foot what can we learn from leprosy? Legacy of Dr Paul W. Brand. Diabetes Metab Res Rev. 28 (1): 37.

6. Kumar D, Banerjee D. 2019. Diabetes and Leprosy: Are they Related?. acta scientific o. 3 (2): 112.

7. Saraya MA, Al-Fadhli MA, Qasem JA. 2012. Diabetic status of patients with leprosy in Kuwait. J Infect
Public Health. 5 (5): 360-5.

8. Nigam P, Dayal SG, Srivastava P, Joshi LD, Goyal BM, Dutt B, et al. 1979. Diabetic status in leprosy. Hansenol Int. 4 (1):7-14.

9. Butlin CR, Hossain D, Singh S, Warrender T. 2017. Diabetes amongst Leprosy-Disabled People in Bangladesh: A Cross-sectional Survey. BIRDEM Med J. 6 (2): 100-6.

10. World Health Organization. Global leprosy update, 2018: moving towards a leprosy free world. Wkly Epidemiol Rec [Internet]. 2019;35/36(94):389-412. Available from:

https://apps.who.int/iris/bitstream/h andle/10665/326775/WER9435-36en-fr.pdf

11. World Health Organization. 2006. Definition and Diagnosis of Diabetes Mellitus and Intermediate Hyperglycemia..

12. Perkumpulan, Endokrinologi, Indonesia, (PERKENI). 2007. Konsensus pengelolaan dan pencegahan diabetes melitus tipe 2 di Indonesia..

13. Sugumaran DST. 1998 Leprosy Reactions and Complications of Steroid Therapy. Int J Lepr. 66 (I): $10-5$.

14. Singh RK, Kumar S, Singh LB. 2013. Diabetic Status Among Leprosy Patients in Referral Centres of Bihar and JharKhand in India.International leprosy congress. (September. 2013)

15. Kemenkes RI. Profil Kesehatan Indonesia 2018, Kementerian Kesehatan RI, Jakarta [Internet]. Jakarta: Kementerian Kesehatan 
Republik Indonesia; 2019. 207 p. Available from: https://www.depkes.go.id/resources/ download/pusdatin/profilkesehatan-indonesia/Data-danInformasi_Profil-KesehatanIndonesia-2018.pdf

16. Kementrian Kesehatan Republik Indonesia. 2018. Laporan Nasional Riskesdas 2018. http://www.depkes.go.id

17. Suastika K, Dwipayana P, Siswadi M, Tuty RA. 2012. Age is an Important Risk Factor for Type 2 Diabetes Mellitus and Cardiovascular Diseases. In: Glucose Tolerance . InTech.

18. Beisel WR, Sawyer WD, Ryll ED, Crozier D. 1967. Metabolic Effects on Intracellular Infections in Man. Ann Intern Med. 67 (4): 744-79.

19. Garg, R; Agrawal, JK; Bajpai, HS; Singh, G; Srivastava P. 1990. Glucose Tolerance Test in Leprosy. Indian J opf Lepr. 62 (50): 4.

20. Papang R, John AS, Abraham S, Rao P. 2009. A study of steroidinduced diabetes mellitus in leprosy. Indian J opf Lepr. 81 (5): 125-9.

21. Ghosh A. 2019. A Central India Perspective on Leprosy and Its Association with Diabetes Mellitus. J Soc Heal Diabetes. 07 (01): 0378. 